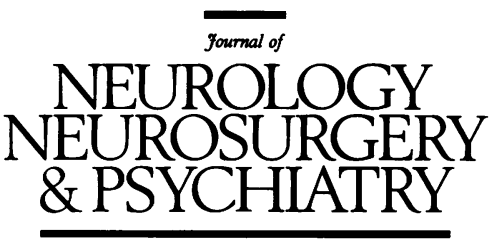

Editorial

\title{
Clinical rationale of genetic testing in dementia
}

The genetic component of some cases of dementia has long been recognised. In 1987 a locus on chromosome 21 was found to be associated with a very aggressive form of Alzheimer's disease with a strong familial transmission (autosomal dominant inheritance). ${ }^{1}$ Four years later the defect was identified in a point mutation of the amyloid precursor protein encoding gene. ${ }^{2}$ Members of families carrying the mutation always developed Alzheimer's disease by about 65 years of age, and members not carrying the mutation did not. The very high penetrance of the mutated trait pointed to amyloid as the potential causative agent of the disease ${ }^{1}$ and suggested the potential use of searching for this mutation in the diagnostic clinical setting. ${ }^{3}$ In subsequent years, the search for other cases of dementia with a genetic component was disappointing. The genetics of some familial dementias were described. These dementias included familial prion diseases, ${ }^{4}$ hereditary cerebral haemorrhages with amyloidosis, Dutch type, ${ }^{5}$ chromosome 17 and chromosome 3 linked forms of frontal lobe dementia, ${ }^{67}$ and cerebral autosomal dominant arteriopathy with subcortical infarcts and leukoencephalopathy (CADASIL). ${ }^{8}$ The genetic defect of Huntington's disease was localised on chromosome $4,{ }^{9}$ and some more pathogenic amyloid precursor protein mutations were discovered, usually with very high penetrance. ${ }^{10-13}$ However, the low frequency of these cases in the overall demented population ${ }^{14}$ led clinicians working on dementia to consider the genetic component to be of little practical relevance. The discovery in 1993 of the association between the highly prevalent late onset form of Alzheimer's disease and the $\varepsilon 4$ allele of the apolipoprotein $\mathrm{E}$ gene (APOE), ${ }^{15}{ }^{16}$ and in 1995 between some families with autosomal dominant Alzheimer's disease and presenilin-1 (PS1) and presenilin-2 (PS2) mutated genes on chromosomes 14 and 1 kindled new interest. ${ }^{17} 18$ Diagnostic kits for APOE genotyping are now commercially available, the presenilin genes have been fully sequenced, the proteins synthesised, and clues to their physiological action are increasingly being discovered. However, the usefulness of these new discoveries in daily clinical practice is often unclear and deserves critical discussion.

This review considers the genetic issues related to Alzheimer's disease as these are the most prevalent in clinical practice, have the largest body of literature, and are those with the most recent and promising developments. Guidelines on genetic testing in Huntington's disease are well established and can be found elsewhere. ${ }^{19} 20$ It is emphasised that the conclusions of this paper should be treated with caution due to the rapid evolution of this field of medicine.

\section{Genetic pathogenic mutations and genetic risk factors: biology and epidemiology}

Genetic studies in dementia are relevant to the understanding of the pathogenesis of the disease, and as clinical tools for diagnosis and prognosis. To understand the theoretical and practical implications of such studies, a brief introduction on amyloid precursor protein, presenilin mutations, and genetic risk factors may be useful.

Mutations of amyloid precursor protein have a very high penetrance, nearly $100 \%^{21}$ and PS1 mutations are similar, ${ }^{17-22}$ suggesting that the encoded proteins might be very close to the core of the biochemical trigger starting the cascade ${ }^{23}$ that leads to neuronal degeneration and death. Presenilins might cause Alzheimer's disease by increasing amyloid deposition in the brain, ${ }^{11}{ }^{24-27}$ further underlining the central role of amyloid in the pathogenesis of Alzheimer's disease. More indirect evidence points to an effect on tangle formation. ${ }^{28} 29$

The search for mutated genes in autosomal dominant Alzheimer's disease has a theoretical basis in the one gene, one disease model, assuming that the Alzheimer's disease "trait" comprises several subtraits, each influenced by a single gene. ${ }^{30}$ It is likely that mutations of amyloid precursor protein, PS1, and PS2 genes are responsible for a very large proportion of all cases of autosomal dominant Alzheimer's disease, ${ }^{31}$ amyloid precursor protein accounting for $2 \%-3 \%$, PS1 for about $50 \%-80 \%$, and PS2 mutations for the remaining $15 \%-20 \%$ (Volga-German kindred). However, autosomal dominant Alzheimer's disease is very rare in practice. What is not rare (at least $25 \%$ of all cases of Alzheimer's disease) ${ }^{32}{ }^{33}$ is a history of dementia in one first degree relative. ${ }^{34} 35$ This criterion is much less stringent than those underlying autosomal dominant inheritance and defines what is often referred to as "familial Alzheimer's disease". Unfortunately, this term has also been given to some kindreds with autosomal

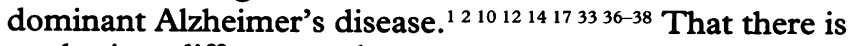
a basic difference between autosomal dominant Alzheimer's disease and familial Alzheimer's disease is supported by the finding that in clinical series in which familial Alzheimer's disease is frequent but autosomal dominant Alzheimer's disease is rare, the frequencies of amyloid precursor protein, PS1, and PS2 mutations are low. ${ }^{14}$ 39-43 
The search for genetic or environmental risk factors in dementia and Alzheimer's disease has a long history. ${ }^{44}$ The discovery of the association of the $\varepsilon 4$ allele of APOE with Alzheimer's disease rightly kindled great interest as for the first time a highly prevalent and easily detectable factor was consistently found related to the disease. Apolipoprotein $\mathrm{E}$ is a lipoprotein carrying cholesterol in the blood, and is the only apolipoprotein produced in the brain, where it has a role in damage repair. ${ }^{45}$ The APOE gene has three common allelic forms, $\varepsilon 2, \varepsilon 3$, and $\varepsilon 4$, with different frequencies (around 5\%-10\%, 75\%-85\%, and $10 \%-15 \%$ in white populations), ${ }^{46}$ coding for the E2, E3, and $\mathrm{E} 4$ protein isoforms. Corder et al $^{15}$ reported a close association between the $\varepsilon 4$ allele of APOE and late onset familial Alzheimer's disease. Members of these families carrying two $(\varepsilon 4 / \varepsilon 4)$ or one ( $\varepsilon 4 /-)$ copy of the $\varepsilon 4$ allele were overrepresented and $\varepsilon 4 / \varepsilon 4$ family members developed Alzheimer's disease more often $(91 \% v 47 \%$ and $20 \%$ ) and earlier (at age $68 v 76$ and 84 years) than $\varepsilon 4 /-$ and non- $\varepsilon 4$ carriers respectively. Cross sectional studies later confirmed the higher frequency of the $\varepsilon 4$ allele in the more prevalent late onset sporadic form. ${ }^{16}$ This finding has been consistently replicated throughout the world, ${ }^{47}$ with very rare exceptions. ${ }^{48-50}$ However, it has become increasingly clear that a relevant proportion of healthy $\varepsilon 4 / \varepsilon 4$ elderly people never develop Alzheimer's disease, and that a relevant proportion of patients with Alzheimer's disease are not $\varepsilon 4$ carriers. ${ }^{51-55}$ These findings indicate that the $\varepsilon 4$ allele has a quantitative trait (involving probabilistic propensities) rather than a one gene, one disease (involving predetermined programming) effect, implying that the Alzheimer's phenotype can be expressed due to the converging effects of the $\varepsilon 4$ allele with other genetic or environmental factors. As a consequence, its biology and clinical application must be distinct from those of the pathogenic mutations. The biological role of apolipoprotein $\mathbf{E}$ in Alzheimer's disease is still unclear. At least three hypotheses have been proposed. It was originally shown that apolipoprotein $\mathrm{E}$ might enhance $\beta$-amyloid deposition in the brain by binding with high avidity. ${ }^{56}$ Alternatively, the E3 isoform might exert a protective effect by slowing phosphorylation of $\tau$-protein and delaying tangle formation. ${ }^{57}$ Others think that the role of apolipoprotein $\mathrm{E}$ in Alzheimer's disease might be due to its physiological effect as a lipid carrier in the brain. The E3 isoform has been shown to cause enhanced and the E4 isoform reduced neurite growth in in vitro studies. ${ }^{45}$ This idea is also supported by findings that the $\varepsilon 4$ allele is a risk factor for incident vascular dementia and poor recovery after head trauma. ${ }^{33} 5859$

Recently, an allelic association similar to that of APOE has been reported for a polymorphism (alleles 1 and 2) in the non-transcripted part of the PS1 gene in a clinical series of 208 patients with Alzheimer's disease, ${ }^{60}$ with homozygosity of the allele 1 of PS1 being responsible for $22 \%$ of cases. Similarly, an allelic association of the very low density lipoprotein receptor gene with sporadic Alzheimer's disease has been reported in Japanese patients $^{61}$ and another association with the $\alpha 1$-antichymotrypsin gene in white ${ }^{62}$ patients. However, attempts to replicate these findings have given conflicting results. ${ }^{63-68}$

\section{Clinical genetic testing}

The use of genetic testing for pathogenic mutations and APOE might be envisaged in a clinical setting-at an individual level-or in an epidemiological setting-at a population level.
GENETIC TESTING AT AN INDIVIDUAL LEVEL

At the individual level genetic testing in the cognitively impaired patient can be used to increase diagnostic accuracy and detect transmissibility. In the as yet cognitively unimpaired subject it can be used to predict disease development and age of onset. The questions arising in autosomal dominant, familial, and sporadic cases are different and require separate discussion.

\section{Autosomal dominant Alzheimer's disease}

Less than 200 kindred with a clearly autosomal dominant form of Alzheimer's disease have been reported. ${ }^{69}$ In dementia research, case ascertainment in pedigrees is more difficult with greater variation in age at onset of the disease in different family members and with older age at onset. ${ }^{70-72}$ However, transmissibility of the disease in these families is often clear. The most relevant issue is the prediction of development of disease in the cognitively unimpaired relatives of a proband. Although data on PS1 and PS2 mutation penetrance are still scarce, it is likely that the detection of one of the known amyloid precursor proteins, PS1, or PS2 mutations in an unaffected relative is associated with a probability of developing the disease close to $100 \%$. However, unaffected relatives are interested to know not only whether they will develop the disease, but also when. Amyloid precursor protein mutations have $100 \%$ penetrance within $2.5 \mathrm{SD}$ from the mean age of onset for the family. ${ }^{21}$ The range of age of onset of Alzheimer's disease associated with mutations of the amyloid precursor protein, PS1, and PS2 genes is very wide if all families are pooled together ( 40 to 65,30 to 65 , and 40 to 90 respectively).$^{73}$ The amount of within family variation of age of onset of the same mutated gene is narrower, at least in PS1 families (about $12^{74} v 20$ years in PS2 fami$\left.\operatorname{lies}^{18}\right)$. However, the range is sufficiently wide in most families to generate great uncertainty on the predictability of age of onset in mutation carriers. ${ }^{1874} 75$ Furthermore, these findings indicate that environmental or other genetic factors have a powerful modulatory effect on the genetic defect. The APOE genotype might be one such factor, in that the $\varepsilon 4$ allele has been shown to reduce the age of onset in families with amyloid precursor protein mutations ${ }^{76}$; however, the $\varepsilon 4$ allele does not have any effect in families with PS1 mutations. ${ }^{36} 37$

The uncertainty of prediction of age at onset by genetic markers is not unique to autosomal dominant Alzheimer's disease; it occurs also in the case of CAG triplet repeats and Huntington's disease. Determination of the CAG triplet can accurately and usefully predict whether a subject at risk will develop Huntington's disease. ${ }^{77}$ It is also known that age of onset of Huntington's disease is related to the number of CAG repeats, a higher number of repeats being associated with younger onset. ${ }^{78}$ However, its $95 \%$ confidence interval for any given number of CAG repeats is over 50 years. ${ }^{79}$ In this case, a genetic factor is responsible for some of the clinical variability, but the contribution is too little to be practically useful. This emphasises the fact that the usefulness of genetic testing in clinical dementia critically depends on the amount of clinical variability accounted for by genetic factors. ${ }^{80}$

Although occasionally the detection of pathogenic mutations can be usefully employed for genetic counselling, ${ }^{81}$ the overall very low prevalence of genetic defects in Alzheimer's disease militates against indiscriminate screening for amyloid precursor protein, PS1, and PS2 mutations in clinical practice. Screening for genetic mutations in specific subpopulations (for example, patients with early onset dementia and very strong family history) might prove cost effective as it would increase the ratio of those with a positive test to those with a negative test. 
Guidelines on when and how to perform predictive genetic testing in autosomal dominant Alzheimer's disease had been provided before the PS1 and PS2 genes had been identified, ${ }^{21}{ }^{32}$ but updated guidelines taking the new findings on presenilins into account are lacking.

\section{Familial Alzheimer's disease}

About 300 familial cases with early onset taken from clinical series have been screened for PS1 and 200 for PS2 mutations. No PS2 mutations have been found, ${ }^{394142}$ and PS1 mutations occurred in $5 \%$ of cases. ${ }^{39-43}$ The prevalence of these mutations in sporadic early onset cases is similar, ${ }^{40424382}$ whereas in the familial late onset cases it is lower. ${ }^{8384}$ Therefore, the usefulness of a routine search for the known mutations in patients with familial Alzheimer's disease seems limited.

Having a family history of Alzheimer's disease on the other hand, does seem to increase the risk of developing the disease ${ }^{85}$ which points to the effect of a genetic factor. Although the genetic factor responsible for this increased susceptibility has not yet been identified, it has been suggested that APOE might account for the familial aggregation. ${ }^{51} 86$ This view is supported by the finding that family history for dementia is more often reported by Alzheimer's disease $\varepsilon 4$ carriers than non- $\varepsilon 4$ carriers. $^{51}$

\section{Sporadic Alzheimer's disease}

The $\varepsilon 4$ allele is more common in patients with sporadic late onset Alzheimer's disease than in elderly controls (about $40 \% v 10 \%-15 \%$ ). ${ }^{16}$ This finding, together with the increased frequency of the $\varepsilon 4$ allele in familial late onset Alzheimer's disease, suggests that the detection of an $\varepsilon 4$ allele in a demented patient might increase the likelihood of the patient having Alzheimer's disease. On these grounds, APOE genotyping has been thought to increase the accuracy of diagnosis of Alzheimer's disease. ${ }^{87} 88$ Roses has argued that the detection of an $\varepsilon 4 / \varepsilon 4$ genotype in a demented patient confers a $95 \%$ probability of Alzheimer's disease.$^{88}$ However, this is true only if the frequency of the $\varepsilon 4$ allele in the non-Alzheimer's disease dementias is not increased. Some authors have reported increased $\varepsilon 4$ allele frequency in Lewy body dementias ${ }^{89} 90$ and vascular dementias. ${ }^{33} 55$ If this is the case, the role of APOE genotyping in the diagnosis of Alzheimer's disease might be less important than previously claimed, ${ }^{91}$ and the value of testing might be disputed.

The most recent guidelines on the use of APOE genotyping in dementia cautiously accept the possibility that APOE genotyping might be a useful confirmatory diagnostic test, but do not recommend its use until fuller epidemiological data are available..$^{92}{ }^{93}$ Recently, Saunders et $a l^{69}$ have shown in a series of 67 necropsied cases of probable Alzheimer's disease ( 57 with Alzheimer's disease confirmed by necropsy and 10 other dementias) that all the $43 \varepsilon 4$ carriers had Alzheimer's disease confirmed at necropsy ( $100 \%$ predictivity). This suggests that APOE genotyping, when restricted to those demented patients clinically diagnosed as probable Alzheimer's disease, might provide a definite diagnosis in about two thirds of cases.

The clinical meaning of APOE genotyping as a predictor of development of disease is less clear. It has been shown with PET that elderly non-demented $\varepsilon 4 / \varepsilon 4$ subjects and relatives of patients with Alzheimer's disease carrying the $\varepsilon 4$ allele have cerebral metabolic defects similar to those of patients with Alzheimer's disease. ${ }^{94} 95$ Furthermore, nondemented elderly $\varepsilon 4$ carriers have $2 \cdot 2$ to $3 \cdot 7$-fold greater risk of developing Alzheimer's disease. ${ }^{52} 55$ These findings contrast with those obtained from cross sectional clinical series indicating a much closer association of the e 4 allele with having Alzheimer's disease (risk of $6 \cdot 2,95 \%$ confidence interval 4.9 to 7.8 in a large series of combined studies). ${ }^{47}$ This means that the high frequency of the $\varepsilon 4$ allele in Alzheimer's disease is only partly due to the increased risk given by the $\varepsilon 4$ allele. The remainder might be due to an enrichment of $\varepsilon 4$ in the Alzheimer's disease population due to longer duration of disease in Alzheimer's disease $\varepsilon 4$ allele carriers, ${ }^{96-98}$ or to impoverishment of the $\varepsilon 4$ allele in the non-Alzheimer's elderly population due to selective cardiovascular mortality in $\varepsilon 4$ allele carriers, ${ }^{99} 100$ or both.

It must be emphasised that currently available guidelines strongly advise against APOE genotyping aimed at disease prediction in asymptomatic subjects. ${ }^{9293}$

\section{GENETIC TESTING AT THE POPULATION LEVEL}

Genetic testing at the population level is aimed at selecting large groups of at risk or affected people for primary or secondary prophylaxis. Whatever estimate of the strength of the association between the $\varepsilon 4$ allele and Alzheimer's disease is accepted, the magnitude of the APOE associated risk for Alzheimer's disease is epidemiologically significant. It has been claimed that about $10 \%$ to $40 \%$ of all cases of Alzheimer's disease are due to the effect of the $\varepsilon 4$ allele, ${ }^{475254101}$ Hence such a proportion of cases might be spared if the risk factor should be eliminated. This has relevant implications for public health, ${ }^{102}$ and research into the therapeutic issues of APOE continues. Alzheimer's disease $\varepsilon 4$ carriers might be differentially responsive to therapy with cognitive enhancers ${ }^{103104}$ and the biology of the E4 isoform in the brain is being investigated with the aim of finding drugs that might counteract its effects. ${ }^{105-107}$

It seems likely that sometime in the future APOE genotyping might be used in screening programmes to select asymptomatic $\varepsilon 4$ carriers for primary prophylaxis ${ }^{102}$ or to increase the sensitivity of epidemiological case finding tools ${ }^{108}$ aimed at detecting early Alzheimer's disease for secondary prophylaxis. ${ }^{109110}$

The clinical applications of genetic testing in dementia are still in their preliminary stages. The search for the known defects can be useful in a limited number of cases, but prediction of age of onset in mutation carriers, even when positive, is fraught with great uncertainty. The $\varepsilon 4$ allele of APOE is an established risk factor for Alzheimer's disease, accounting for $10 \%-40 \%$ of all the cases, but its usefulness as a diagnostic test for Alzheimer's disease must be confirmed, and its role as a screening tool in populations must be assessed in future studies. There is also a need to compute reliable estimates of the age specific risk for Alzheimer's disease associated with the $\varepsilon 4 / \varepsilon 4$ and $\varepsilon 4 /-$ genotypes. To be clinically useful, genetic research work in dementia will need to shift from the one gene, one disease theory towards the quantitative trait model to provide estimates of the amount of clinical variability that can be accounted for by genetic factors.

We thank Angelo Bianchetti, Head, Alzheimer's Unit, S Cuore-FBF We thank Angelo Bianchetti, Head, Alzheimer's Unit, S Cuore-FBF
Hospital, for his invaluable suggestions before, during, and after the preparation of the manuscript, and Professor Stefano Govoni for his constant criticism. Drs Gomez-Isla and Campion provided information on personal data.

GB FRISONI M TRABUCCH

Alzheimer's Unit, IRCCS-AFAR 5 Giovanni di Dio, and Geriatric Research Group, Brescia, Italy

Correspondence to: Dr Giovanni B Frisoni, Geriatric Research Group, via Romanino 1, 25122 Brescia, Italy.

1 St George-Hyslop PH, Tanzi RE, Polinski RJ, et al. The genetic defect causing familial Alzheimer's disease maps on chromosome 21. Science 1987;235:885-90.

2 Goate A, Chartier-Harlin M-C, Mullan M, et al. Segregation of a missense mutation in the amyloid precursor protein gene with familial Alzheimer's

3 Clark RF, Goate AM. Molecular genetics of Alzheimer's disease. Arch Neurol 1993;50:1164-72. 
4 Collinge J, Palmer MS. Prion diseases in humans and their relevance to other neurodegenerative diseases. Dementia 1993;4:178-85.

5 Van Broeckhoven C, Haan J, Bakker B, et al. Amyloid $\beta$ protein precursor gene and hereditary cerebral hemorrhage with amyloidosis. Science 1990;248:1120-2. (In Dutch.)

6 Wilhelmsen KC, Lynch T, Pavlou E, et al. Localization of disinhibitiondementia-parkinsonism-amyotrophy complex (DDPAC) to $17 \mathrm{q} 21-22$ Am f Hum Genet 1994;55:1159-65.

7 Brown J, Ashworth A, Gydesen S, Sorensen A, Rossor M, Hardy J, Collinge J. Familial non-specific dementia maps to chromosome 3. Hum Mol Genet 1995;4:1625-8.

8 Tournier-Lasserve E, Joutel A, Melki J, et al. Cerebral autosomal dominant arteriopathy with subcortical infarcts and leukoencephalopathy maps to chromosome 19q12. Nat Genet 1993;3:256-9.

9 The Huntington's Disease Collaborative Research Group. A novel gene containing a trinucleotide repeat that is expanded and unstable on Huntington's disease chromosomes. Cell 1993;72:971-83.

10 Bird TD. Clinical genetics of familial Alzheimer disease. In: Terry RD, Katzmann R, Bick KL, eds. Alzheimer disease. New York: Raven Press 1944:65-74.

11 Hardy J. New insights into the genetics of Alzheimer's disease. Ann Med 1996;28:255-8.

12 Lennox A, Karlinski H, Meschino W, Buchanan JA, Percy ME, Berg JM. Molecular genetic predictive testing for Alzheimer's disease: deliberaions and preliminary recommendations. Alzheimer Dis Assoc Disord 1994;8:126-47.

13 St George-Hyslop PH. The molecular genetics of Alzheimer disease. In: Terry RD, Katzmann R, Bick KL, eds. Alzheimer disease. New York: Raven Press 1944:345-52.

14 Tanzi RE, Vaula G, Romano DM, et al. Assessment of amyloid $\beta$-protein precursor gene mutations in a large set of familial and sporadic Alzheimer disease cases. Am f Hum Genet 1992;51:273-82.

15 Corder EH, Saunders AM, Strittmatter WJ, et al. Gene dose of apolipoprotein E type 4 allele and the risk of Alzheimer's disease in late onset families. Science 1993;261:921-3.

16 Saunders AM, Strittmatter WJ, Schmechel D, et al. Association of apolipoprotein $\mathrm{E}$ allele $\varepsilon 4$ with late-onset familial and sporadic Alzheimer's disease. Neurology 1993;43:1467-72.

17 Sherrington R, Rogaev EI, Liang Y, et al. Cloning a gene bearing missense mutations in early-onset familial Alzheimer's disease. Nature mutations in ear

18 Levy-Lahad E, Wijsman EM, Nemens E, et al. A familial Alzheimer's disease locus on chromosome 1. Science 1995;269:970-3.

19 World Federation of Neurology: Research Committee. Research Group on Huntington's Chorea. Ethical issues policy statement on Huntington's disease molecular genetics predictive test. F Neurol $S c i$ 1989;94:327-32. 20 Went $\mathrm{L}$. Ethical issues policy statement on Huntington's

21 Mullan M, Crawford F, Buchanan J. Technical feasibility of genetic testing for Alzheimer's disease. Alzheimer Dis Assoc Disord 1994;8:102-15.

22 Rossor MN, Fox NC, Beck J, Campbell TC, Collinge J. Incomplete penetrance of familial Alzheimer's disease in a pedigree with a novel presenilin-1 gene mutation [letter]. Lancet 1996;347:1560.

23 Hardy JA, Higgins GA. Alzheimer's disease: the amyloid cascade hypothesis. Science 1992;256:184-5.

24 Querfurth PH, Wijsman EM, St George-Hyslop PH, et al. $\beta$ APP mRNA is increased in cultured fibroblasts from the familial Alzheimer's disease-1 family. Mol Brain Res 1995;28:319-37.

25 Scheuner D, Eckman C, Jensen $M$, et al. Secreted amyloid- $\beta$-protein similar to that in the senile plaques of Alzheimer's disease is increased in vivo by the presenilin 1 and 2 and APP mutations linked to familial Alzheimer's disease. Nat Med 1996;8:864-70.

26 Duff K, Eckman C, Zehr C, et al. Increased amyloid- $\beta-42(43)$ in brains of mice expressing mutant presenilin 1. Nature 1996;383:710-3.

27 Mann DMA, Iwatsubo T, Cairns NJ, et al. Amyloid $\beta$ protein (A $\beta$ ) deposition in chromosome 14-linked Alzheimer's disease: predominance of $\mathrm{A} \beta_{42(43)}$. Ann Neurol 1996;40:149-56.

28 Dickson DW, Liu W-K, Yen S-H. An antibody to an amino-terminal domain of presenilin-1 immunostains neurofibrillary tangles in Alzheimer's disease [ abstract]. Neurobiol Aging 1996;17:S18

29 Bouras C, Giannakopoulos P, Schioi J, Tezapsidis N, Robakis NK. Presenilin-1 polymorphism and Alzheimer's disease [letter]. Lancet 1996;347:1185-6.

30 Plomin R, Owen MJ, McGuffin P. The genetic basis of complex human behaviors. Science 1994;264:1733-9.

31 Barinaga M. Missing Alzheimer's gene found. Science 1995;269:917-8.

32 Medical and Scientific Advisory Committee, Alzheimer's Disease International. Consensus statement on predictive testing for Alzheimer disease. Alzheimer Dis Assoc Disord 1995;9:182-7.

33 Frisoni GB, Calabresi L, Geroldi C, et al. Apolipoprotein E $\varepsilon 4$ allele in Alzheimer's disease and vascular dementia. Dementia 1994;5:240-2.

34 Silverman JM, Breitner JCS, Mohs RC, Davis KL. Reliability of the family history method in genetic studies of Alzheimer's disease and related dementias. Am ₹ Psychiatry 1986;143:1279-82.

35 Silverman JM, Raiford K, Edland S, et al. The consortium to establish a registry for Alzheimer disease (CERAD). Part VI. Family history assessment: a multicenter study of first-degree relatives of Alzheimer's disease proband

36 Van Broeckhoven $\mathrm{C}$, Backhovens $\mathrm{H}$, Cruts $\mathrm{M}$, et al. ApoE genotype does not modulate age of onset in families with chromosome 14 encoded Alzheimer's disease. Neurosci Lett 1994;169:179-80.

37 St George-Hyslop PH, Crapper McLachlan D, Tuda T, Rogaev E. Alzheimer's disease and possible gene interaction. Science 1994;263:537.

38 Sherrington R, Froelich S, Sorbi S, et al. Alzheimer's disease associated with mutations in presenilin 2 is rare and variably penetrant. Hum Mol Genet 1996;5:985-8.

39 Campion D, Brice A, Agid Y, et al. Genetic studies of Alzheimer's disease in 434 French families [abstract]. Neurobiol Aging 1996;17:S195.

40 Sandbrink R, Zhang D, Hartmann T, et al. Missense mutations of the presenilin 1 gene (PS1 or S182) in German early-onset Alzheimer's disease patients [abstract]. Neurobiol Aging 1996;17:S12.

41 Forsell C, Froelich S, Axelman K, et al. Mutations in the presenilin I and II genes are rare in early-onset Alzheimer's disease in Sweden [abstract]. Neurobiol Aging 1996;17:S13.
42 Tabira $\mathrm{T}$, Tanahashi $\mathrm{H}$, Yamanaka $\mathrm{H}$, et al. Genetic analysis of familial Alzheimer's disease in Japan [abstract]. Neurobiol Aging 1996;17:S150.

43 Gomez-Isla T, Wasco W, Pettingell WP, et al. A novel mutation in the chromosome 14 familial Alzheimer's disease gene [abstract]. Neurology 1996;46:A249.

44 Rocca WA, Amaducci L. Epidemiology of Alzheimer's disease. In: Anderson DW, Shoenberg DG, eds. Neuroepidemiology. Boca Raton, FL CRC press, 1991:55-96.

45 Nathan BP, Bellosta S, Sanan DA, Weisgraber KH, Pitas RE. Differential effects of apolipoproteins E3 and E4 on neuronal growth in vitro. Science 1994:264:850-2.

46 Gerdes LU, Klausen IC, Sihm I, Færgeman O. Apolipoprotein E polymorphism in a Danish population compared to findings in 45 other study populations around the world. Genet Epidemiol 1992;9:155-67.

47 Nalbantoglu J, Gilfix BM, Bertrand P, et al. Predictive value of apolipoprotein E genotyping in Alzheimer's disease: results of an autopsy series and an analysis of several combined studies. Ann Neurol 1994;36:889-95.

48 Mayeux R, Stern Y, Ottman R, et al. The apolipoprotein $\varepsilon 4$ allele in patients with Alzheimer's disease. Ann Neurol 1993;34:752-4.

49 Pericak-Vance MA, Johnson CC, Rimmler JB, et al. Alzheimer's disease and apolipoprotein E-4 allele in an Amish population. Ann Neurol 1996;39:700-4.

50 Lannfelt L, Lilius L, Nastase $M$, et al. Lack of association between apolipoprotein E allele $\varepsilon 4$ and sporadic Alzheimer's disease. Neurosci Lett 1994;168:254-6.

51 Henderson AS, Easteal S, Jorm AF, et al. Apolipoprotein E allele $\varepsilon 4$, dementia, and cognitive decline in a population sample. Lancet 1995;346:1387-90.

52 Evans DA. Apolipoprotein E $\varepsilon 4$ status and risk of Alzheimer's disease: incidence and prevalence studies from a geographically defined community [abstract]. The Lancet Conference: The challenge of the dementias, April 25-26, 1996. Edinburgh, Scotland: Lancet, 1996.

53 Hyman BT, Gomez-Isla T, Briggs M, et al. Apolipoprotein E and cognitive change in an elderly population. Ann Neurol 1996;40:55-6.

54 Feskens EJM, Havekes LM, Kalmijn S, de Knijff P, Launer LJ, Kromhout D. Apolipoprotein $\varepsilon 4$ allele and cognitive decline in elderly men. $B M F$ 1994;309:1202-6.

55 Myers RH, Schaefer EJ, Wilson PWF, et al. Apolipoprotein E $\varepsilon 4$ association with dementia in a population-based study: the Framingham study. Neurology 1996;46:673-7.

56 Strittmatter WJ, Saunders AM, Schmechel D, et al. Apolipoprotein E: high avidity binding to $\beta$-amyloid and increased frequency of type 4 allele in late-onset familial Alzheimer disease. Proc Nat Acad Sci USA 1993;90:1977-81

57 Strittmatter WJ, Weisgraber $\mathrm{KH}$, Goedert $\mathbf{M}$, et al. Hypothesis: microtubule instability and paired helical filament formation in the Alzheimer disease brain are related to apolipoprotein E genotype. Exp Neurol 1994;125:163-71.

58 Nicoll JAR, Roberts GW, Graham DI. Apolipoprotein E $\varepsilon 4$ allele is associated with deposition of amyloid b-protein following head injury. Nat Med 1995;1:135-7.

59 Sorbi S, Nacmias B, Piacentini S, et al. ApoE as a prognostic factor for post-traumatic coma [letter]. Nat Med 1995;1:852.

60 Wragg M, Hutton M, Talbot C, and the Alzheimer's Disease Collaborative Goup. Genetic association between intronic polymorphism in presenilin1 gene and late-onset Alzheimer's disease. Lancet 1996;347:509-12.

61 Okuizumi K, Onodera O, Namba Y, et al. Genetic association of the very low density lipoprotein (VLDL) receptor gene with sporadic Alzheimer's disease. Nat Genet 1995;11:207-9.

62 Kamboh MI, Sanghera DK, Ferrell RE, DeKosky ST. APOE*4-associated Alzheimer's disease risk is modified by $\alpha 1$-antichymotrypsin polymorphism. Nat Genet 1995;10:486-8.

63 Chung H, Roberts CT, Greenberg S, et al. Lack of association of trinucleotide repeat polymorphism in the very-low-density lipoprotein receptor gene with Alzheimer's disease. Ann Neurol 1996;39:800-3.

64 Pérez-Tur J, Wavrant-De Vrieze F, Lambert JC, Chartier-Harlin M-C, and the Alzheimer's Study Group. Presenilin-1 polymorphism and Alzheimer's disease [letter]. Lancet 1996;347:1560-1.

65 Kehoe P, Williams J, Lovestone S, Wilcock G, Owen MJ, and the Alzheimer's Study Group. Presenilin-1 polymorphism and Alzheimer's disease [letter]. Lancet 1996;347:1185.

66 Scott WK, Growdon JH, Roses AD, Haines JL, Pericak-Vance MA. Presenilin-1 polymorphism and Alzheimer's disease [letter]. Lancet 1996;347:1186-7.

67 Higuchi S, Muramatsu T, Matsushita S, Arai H, Sasaki H. Presenilin-1 polymorphism and Alzheimer's disease [letter]. Lancet 1996;347: 1186 .

68 Haines JL, Pritchard ML, Saunders AM, et al. No genetic effect of $\alpha 1$ antichymotrypsin in Alzheimer's disease. Genomics 1996;33:53-6.

69 Saunders AM, Hulette C, Welsh-Bohmer KA, et al. Specificity, sensitivity, and predictive value of apolipoprotein-E genotyping for sporadic Alzheimer's disease. Lancet 1996;348:90-3.

70 Farrer LA, O'Sullivan DM, Cupples LA, Growdon JH, Myers RH. Assessment of genetic risk for Alzheimer's disease among first-degree relatives. Ann Neurol 1989;25:485-93.

71 Morton NE. Outline of genetic epidemiology. Basel: Karger, 1982:69-88.

72 Thompson EA. Pedigree analysis in human genetics. Baltimore: Johns Hopkins, 1986.

73 Writing Committee, Lancet Conference 1996. The challenge of the dementias. Genetics and biomarkers. Lancet 1996;347:1304-5.

74 Schellenberg GD, Bird TD, Wijsman EM, et al. Genetic linkage evidence for a familial Alzheim

75 Axelman K, Lannfeit L. Variable age of onset in an Alzheimer family with a His 163Arg mutation in the presenilin 1 gene [abstract]. Neurobiol Aging His 163Arg mug;17:S13.

76 Hardy J, Houlden H, Collinge J, et al. Apolipoprotein E genotype and Alzheimer's disease. Lancet 1993;343:737-8.

77 Wiggins S, Whyte $P$, Huggins $M$, et al. The psychological consequences of predictive testing for Huntington's disease. $N$ Engl $f \mathrm{Med}$ 1992;327:1401-5.

78 Claes S, Van Zand K, Legius E, et al. Correlation between triplet repeat expansion and clinical features in Huntington's disease. Arch Neurol 1995;113:749-53.

79 Gallucci D, Frisoni GB, Trabucchi M, Appollonio M. The relevance of 
genetic testing in late-onset Huntington's disease [letter]. $\mathcal{f} \mathrm{Am}$ Geriatr Soc 1996;44:609-11.

80 Parens E. Taking behavioral genetics seriously. Hastings Cent Rep 1996;26:13-8

81 Lannfelt L, Axelman K, Lilius L, Basun H. Genetic counseling in a Swedish Alzheimer family with amyloid precursor protein mutation [letter]. Am ₹ Hum Genet 1995;56:332-5.

82 Zhang D, Sandbrink R, Tienari P, et al. Polymorphism of the presenilin 2 gene (PS2, STM2 or E51) in German sporadic Alzheimer's disease patients [abstract]. Neurobiol Aging 1996;17:S195.

83 Pericak-Vance MA, Gaskell PC, Conneally PM, et al. Complete genomic screen in late-onset familial Alzheimer disease [abstract]. Neurobio Aging 1996;17:S59.

84 Froelich S, Engvall B, Forsell C, et al. A search for susceptibility genes in ate-onset Alzheimer's disease [abstract]. Neurobiol Aging 1996;17: S59.

85 Silverman JM, Li G, Zaccario M, et al. Patterns of risk in first-degree relatives of patients with Alzheimer's disease. Arch Gen Psychiatry 1994;51: tives of pat 86.

86 Houlden H, Crook R, Hardy J, Roques P, Collinge J, Rossor M Confirmation that familial clustering and age of onset in late onset Confirmation that familial clustering and age of onset in late onset Alzheimer's disease are dete

87 Roses AD, Strittmatter WJ, Pericak-Vance MA, Corder EH, Saunders AM, Schmechel DE. Clinical application of apolipoprotein E genotyping to Alzheimer's disease [letter]. Lancet 1994;343:1564-5.

88 Roses $\mathrm{AD}$. Apolipoprotein $\mathrm{E}$ genotyping in the differential diagnosis, no prediction, of Alzheimer's disease. Ann Neurol 1995;38:6-14.

89 Pickering-Brown SM, Mann DMA, Bourke JP, et al. Apolipoprotein E4 and Alzheimer's disease pathology in Lewy body disease and in other bamyloid-forming diseases [letter]. Lancet 1994;343:1155.

90 Arai H, Higuchi S, Muramatsu T, Iwatsubo T, Sasaki H, Trojanowski JQ Apolipoprotein $\mathrm{E}$ gene in diffuse Lewy body disease with or without coexisting Alzheimer's disease [letter]. Lancet 1994;344:1307.

91 Frisoni GB, Bianchetti A, Govoni S, Trabucchi M. Diagnostic usefulness of apolipoprotein E e4 in the diagnosis of the dementias [letter]. $\mathcal{F}$ Neurol Neurosurg Psychiatry 1996;60:699-700.

92 American College of Medical Genetics/American Society of Human Genetics Working Group on ApoE and Alzheimer Disease. Statement on use of apolipoprotein $\mathrm{E}$ testing for Alzheimer disease. $\mathcal{F} A M A$ 1995;274:1627-9.

93 National Institute on Aging/Alzheimer's Association Working Group. Apolipoprotein E genotyping in Alzheimer's disease. Lancet 1996;347:1091-5.

94 Reiman EM, Caselli RJ, Yun LS, et al. Preclinical evidence of Alzheimer's disease in persons homozygous for the $\varepsilon 4$ allele of apolipoprotein $\mathrm{E}$. $N$
Engl f Med 1996;334:752-8

95 Small GW, Mazziotta JC, Collins MT, et al. Apolipoprotein E type 4 allele and cerebral glucose metabolism in relatives at risk for familial Alzheimer disease. $¥ A M A$ 1995;273:942-7.

96 Frisoni GB, Calabresi L, Geroldi C, et al. Gene dose of the $\varepsilon 4$ allele of apoliprotein $\mathrm{E}$ and gender in sporadic late-onset Alzheimer's disease. Ann Neurol 1995;37:596-604.

97 van Duijn CM, de Knijff P, Wehnert A, et al. The apolipoprotein E $\varepsilon 2$ allele is associated with an increased risk of early-onset Alzheimer's disease and a reduced survival. Ann Neurol 1995;37:605-10.

98 Sarochan M, Foerstl H, Sattel H, Zerfass R, Czech C, Beyreuther K. Apolipoprotein E genotype does not promote the clinical progression of manifest Alzheimer's disease [letter]. Dementia 1996;7:120.

99 Riggs J, Keefover $R$. The association between apolipoprotein $E$ allele $\varepsilon 4$ and late-onset Alzheimer's disease: pathogenic relationship or differential survival bias? [letter]. Arch Neurol 1994;51:750.

100 Cauley JA, Eichner JE, Kamboh MI, Ferrell RE, Kuller LH. ApoE allele frequencies in younger (age 42-50) vs older (age 65-90) women. Genet Epidemiol 1993;10:27-34.

101 Mayeux R. Understanding Alzheimer's disease: expect more genes and other things. Ann Neurol 1996;39:689-90.

102 Post SG. Genetics, ethics, and Alzheimer disease. $7 \mathrm{Am}$ Geriatr Soc 1994;42:782-6.

103 Poirier J, Delisle M-C, Quirion R, et al. Apolipoprotein E4 allele as a predictor of cholinergic deficits and treatment outcome in Alzheimer disease. Proc Natl Acad Sci USA 1995;92:12260-4.

104 Amouyel P, Neuman E, Dillemenn, et al. Characterization of the apolipoprotein E genotypes in a European multicenter trial on Alzheimer's disease with the S-12024-2 (memory enhancer). Neurology 1996;46:A218.

105 Strittmatter WJ. Apolipoprotein E / protein interactions: developing therapeutic strategies [abstract]. Neurobiol Aging 1996;17:S83.

106 Huang DY, Weisoraber KH, Goedert M, Saunders AM, Roses AD, Strittmatter WJ. ApoE3 binding to tau tandem repeat I is abolished by tau serine 262 phosphorylation. Neurosci Lett 1995;192:209-12.

107 Huang DY, Weisgraber KH, Strittmatter WJ, Matthew WD. Interaction of apolipoprotein $\mathrm{E}$ with laminin increases neuronal adhesion and alters of apolipoprotein E with laminin increases neuron

108 Folstein M, Folstein S, McHugh P. The mini-mental state examination. $f$ Psychiatr Res 1975;12:189-98.

109 Frisoni GB, Geroldi C, Bianchetti A, Binetti G, Trabucchi M. The gain of apolipoprotein $\mathrm{E}$ genotyping to separate Alzheimer's disease from normal individuals: relevance to community studies. Dementia 1996;7:336-42.

110 Writing Committee, Lancet Conference 1996. The challenge of the dementias. Epidemiology. Lancet 1996;347:1303-4.

\section{NEUROLOGICAL STAMP}

\section{Julius Wagner-Jauregg (1857-1940)}

The Austrian neuropsychiatrist Julius Wagner-Jauregg was born in Wels in 1857. He studied medicine in Vienna, where he earned his "venia legendi", an advanced doctoral degree required for university lecturers, in 1885. He spent four years at the University Clinic in Graz before becoming head of the Viennese Department of Psychiatry, a position he held from 1893 to 1928 . His intensive study of cretinism served as a basis for his specialisation in the problems of goitre. In 1887 he published a paper on the influence of feverish illnesses on psychoses, and 30 years later, during the first world war, introduced the use of iatrogenic Plasmodium vivax infection in the treatment of late symptomatic neurosyphilis. $\mathrm{He}$ was awarded the Nobel prize in 1927 for discovering the therapeutic value of this "malaria vaccination" in the treatment of progressive paralysis. Julius Wagner-Jauregg died in Vienna on 7 September 1940. Austria issued a commemorative stamp in honour of the 100th anniversary of the Nobel prizewinner's birth.

FRANZ ALLERBERGER

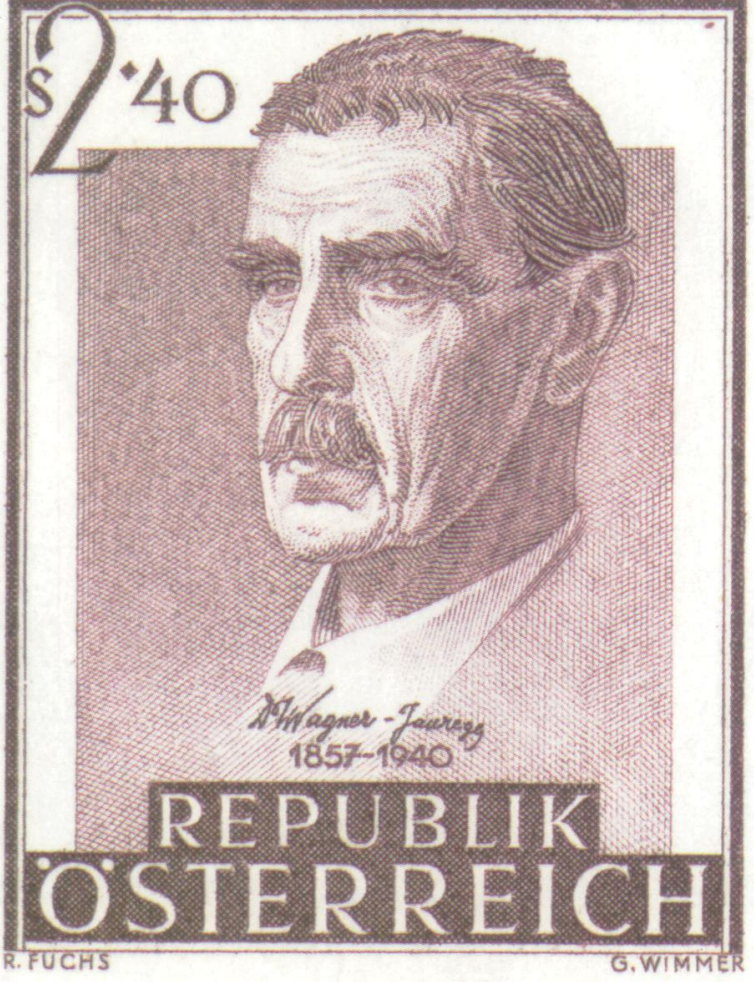

